Article

\title{
Adapting to a Global Health Challenge: Managing Antimicrobial Resistance in the Nordics
}

\author{
Martin Stangborli Time ${ }^{1}$ and Frode Veggeland ${ }^{2, *}$ \\ ${ }^{1}$ Department of Political Science and Management, University of Agder, 4604 Kristiansand, Norway; \\ E-Mail: martin.s.time@uia.no \\ 2 Department of Health Management and Health Economics, University of Oslo, 0317 Oslo, Norway; \\ E-Mail: frode.veggeland@medisin.uio.no \\ * Corresponding author
}

Submitted: 15 June 2020 | Accepted: 22 September 2020 | Published: 3 November 2020

\begin{abstract}
This article explores the adaptation of Norway and Sweden to one of the major challenges to global public health, antimicrobial resistance (AMR). Guided by assumptions derived from institutional theory, the article investigates whether, and, if so, how the AMR problem has affected the two Nordic countries' administrative systems and frameworks for Nordic cooperation. The article builds on selected literature, expert interviews, and public documents. The findings suggest that the international impact on Norway and Sweden's managerial adaptation to AMR is limited. Instead, adaptation takes place through incremental change within existing structures for disease prevention and control and follows traditional ways of organizing political and administrative systems.
\end{abstract}

\section{Keywords}

antimicrobial resistance; disease control; disease prevention; Europeanization; Nordic cooperation; Norway; public administration; Sweden

\section{Issue}

This article is part of the issue "Rediscovering Nordic Cooperation" edited by Anne Elizabeth Stie (University of Agder, Norway) and Jarle Trondal (University of Agder, Norway/ARENA University of Oslo, Norway).

(C) 2020 by the authors; licensee Cogitatio (Lisbon, Portugal). This article is licensed under a Creative Commons Attribution 4.0 International License (CC BY).

\section{Introduction}

The Coronavirus pandemic in 2020 appeared as a defining global health crisis facing national governments with extreme challenges of crisis management and cooperation. The crisis revealed that nation-states chose a variety of different approaches to the management of the same major health threat. Even in a relatively homogenous region such as the Nordic region, there was variation among the countries' approaches. The crisis demonstrated the need for effective mechanisms of preparedness, coordination, and management in health governance. This article will explore the management of one of the other big challenges to global public health identified by the World Health Organisation (WHO), namely antimicrobial resistance (AMR). The WHO's prioritization of AMR management became particularly apparent in 2015 when the WHO's Global Action Plan was published (WHO, 2015). The Global Action Plan represented a key event in global health governance by providing guidelines for AMR management and encouraging all WHO members to implement national action plans for AMR. Thus, the WHO provided a framework for global influence on AMR management. The increase of AMR implies that a growing number of antibiotics become ineffective and thus contribute to an increasing number of deaths worldwide. It is estimated that within the EU, annually, AMR is responsible for approximately 33,000 deaths and approximately EUR 1.5 billion in healthcare costs and productivity losses (Cassini et al., 2018; Organisation 
for Economic Co-operation and Development [OECD], 2018). Some estimates show that, without effective policies, by 2050 as many as 10 million people may die each year from causes related to AMR (O'Neill, 2014). Managing the problem of AMR is a complex endeavour as it (similar to Covid-19) both spreads across national borders and affects different sectors. Thus, AMR represents a major challenge to all levels of governance, including Nordic cooperation. This article investigates Norwegian and Swedish adaptation to the AMR problem, with an emphasis on the two countries' administrative systems and frameworks for international (Nordic, European, global) cooperation. The main research questions are: (a) How have the central administrative systems of Norway and Sweden adapted to the AMR challenge? And (b) has the adaptation to AMR strengthened Nordic cooperation or has Nordic cooperation been surpassed by international influence (EU, WHO) and/or by unique national characteristics? The key puzzle, which the article addresses, is whether, and, if so, how and why nation-states' adaptation to a major common challenge leads to changes in domestic administrative structures, as well as in cooperation patterns across national borders. Thus, the article aims to increase the understanding of the conditions for collective action and institutional adaptation in the face of common external threats. The study reveals barriers against standardized responses to crosscutting challenges such as AMR and highlights the need for country-specific historical and institutional contexts to be taken into account when managing major cross-border challenges.

The Nordic countries have a long tradition of cooperation on health-related matters. Of particular importance has been the common Nordic labour market, established in 1954, and the related social security agreement from 1955 giving Nordic citizens more or less the same welfare services when working in other Nordic countries (Pedersen, Røed, \& Wadensjö, 2008). Beyond this, Nordic cooperation on health has been characterized by 'soft modes of cooperation,' i.e., by non-binding commitments and network activities, involving in particular experts and researchers. One example of such networks is the Northern Dimension Partnership in Public Health and Social Well-being (NDPHS), which, among other things, includes an expert group on AMR. The EU has added important elements to the Nordic cooperation by requiring that all members implement EU law. Norway is required to implement such rules through the EEA Agreement. However, even though network activities are included also in EU cooperation, the EU's formal competences in health are limited. Thus, the core responsibilities for national health systems remain in the hands of the nation-states. Hence, when dealing with major health challenges such as AMR, Norway and Sweden have been relatively free to choose which tools and measures to use within their administrative systems. In the following paragraphs, derived from institutional theo$r y$, we generate assumptions about the adaptation to the AMR challenge within the Nordics - with a particular focus on Norway and Sweden.

\section{Institutional Approach to Adaptation: Internal and External Factors}

Based on institutional theory, this section aims to generate assumptions about the Nordic adaptation to the AMR problem by presenting two perspectives, which emphasize internal and external factors, respectively.

The internal perspective lends inspiration from historical institutionalism and the concept of path dependency and emphasizes factors rooted in the historical development and specific institutional characteristics within the nation-states. Here, adaptation takes place through incremental steps (Lindblom, 1959; Mahoney \& Thelen, 2010) or path-dependent choices (Pierson, 2000; Pollitt, 2008) and is characterized by stability and institutional continuity. One of the (indirect) basic assumptions within this literature is that dramatic change is primarily triggered by shocks, major events, or critical junctures which create 'windows of opportunity' for innovation and transformative change (Kingdon, 1995; Pierson, 2004). Derived from the internal perspective, we pose two alternative assumptions:

(i) Adaptation to the AMR challenge is pathdependent, based on well-established and unique administrative structures and routines for handling the same types of problems. Thus, managing AMR is characterized by incremental changes and minor adjustments, which only add to (and do not replace) pre-existing structures and routines within the Nordic administrative systems.

(ii) The AMR challenge represents a major eventa critical juncture-which strengthens the efforts to learn from each other within the Nordics and which leads to the establishment of innovative and new administrative structures within Nordic cooperation.

The external perspective lends inspiration from theories of diffusion and Europeanization-emphasizing factors, which are rooted in events taking place outside of the Nordic cooperation, as well as outside national governments' direct control. Two sets of factors are highlighted: First, the EU influences domestic administrations through the adoption of binding, as well as non-binding commitments. This relates to the idea that the EU may be a source of influence that contributes to a "central penetration of national systems of governance" and leads to the adaptation of "national and sub-national systems of governance to a European political centre and European-wide norms" (Olsen, 2002, pp. 923-924). Here, adaptation takes place by implementing and adhering to authoritative decisions and recommendations adopted at the EU level (Bondarouk \& Mastenbroek, 2018; Treib, 2014). The second set of exter- 
nal factors are rooted in global ideas and initiatives. Here, influence is not channelled through one particular central authority above the nation-states (such as the EU), but instead via horizontal mechanisms such as epistemic communities (Haas, 2016), cooperative networks, and information exchanges between governments, thus triggering a potential for diffusion of common global ideas and norms (Boxenbaum \& Jonsson, 2017). Thus, adaptation takes place on the basis of peer pressure, learning, and imitation/copying. A key concept in the context of $A M R$, and relevant to the article's external perspective, is the 'One Health' principle, which pervades international strategic documents on the issue (c.f. European Commission, 2017; European Council, 2016; WHO, 2015). 'One Health' is here understood as a global template for administrative adaptation to enable the fight against AMR. Accordingly, "stemming the superbug tide" (OECD, 2018) necessitates the engagement of "everybody-in all sectors and disciplines-in the implementation of the [global] action plan on AMR" (WHO, 2015, p. 5). Adapting management structures to 'One Health,' thus places demand on public administrations to extend their horizontal (cross-sector) and vertical (multi-level) lines of coordination. Derived from the external perspective, we pose two alternative assumptions:

(i) EU influence surpasses unique Nordic approaches and contributes to the implementation of European specific solutions to the management of the AMR crisis.

(ii) Global initiatives lead to the diffusion of global norms, standards, and ideas, which surpass Nordic cooperation and contribute to the convergence of national systems of AMR management in line with the 'One Health' principle.

\section{Methods and Data}

The article presents a study of Norway, Sweden, and the Nordic cooperation's response to the AMR challenge. The article's ambition is mainly empirical, but it also seeks to substantiate a number of assumptions derived from institutional theory in order to establish whether, and, if so, how and why the AMR problem has affected the administrative systems and cooperative framework of the Nordic countries. Norway and Sweden are both: (a) part of the Nordics, (b) small and wealthy welfare states with modern administrative systems and similar cultures, and (c) strongly linked to the EU (Sweden as a member, Norway as part of the EEA Agreement). There is a long tradition of learning from each other within the Nordic cooperation, hence the likelihood of cross-border policy diffusion regarding AMR management. For the time being, the Nordic countries seem able to keep the burdens of AMR at bay (c.f. Cassini et al., 2018, p. 6). Furthermore, all four countries score below average (with Sweden scoring lowest) in the EU/EEA-area measurement on antimicrobial consump- tion in the primary care and hospital sector (2018 data; European Centre for Disease Prevention and Control [ECDC], 2020). Measured by sales of veterinary antimicrobial agents marketed mainly for food-producing animals (2017 data), the Nordic countries also seem to be on the right path. Thus, Norway reports the lowest numbers in Europe $(3.1 \mathrm{mg}$ sold per population correction unit [PCU]) with the numbers for Sweden, Finland, and Denmark being 11.8, 19.3, and $39.4 \mathrm{mg} / \mathrm{PCU}$, respectively. In comparison, the highest-scoring member state reported $423.1 \mathrm{mg} / \mathrm{PCU}$ (European Medicines Agency, 2019 , p. 24). All Nordic countries score well below the mean for Europe with regard to AMR prevalence (ECDC, 2018), even though Denmark continues to have a greater problem than the others regarding some multi-resistant bacteria in humans, food animals, and meat (DANMAP, 2019 , p. 2). Nonetheless, compared to other regions in Europe, the Nordic region as a whole so far stands out as successful in maintaining a low prevalence of AMR. Both Norway and Sweden are active participants in the international work on AMR and both countries stress the importance of international cooperation in this area. Thus, one key question raised in this article is whether this active international engagement has paved the way for international rules and recommendations on AMR management to influence AMR management and administrative structures in the Nordics. The data of the article consists of selected literature, written transcripts from 20 expert interviews (see Supplementary File for a comprehensive overview) and 'grey' literature (legal documents, strategies, action plans, reports). The interview data were generated over a three-year period (2017-2020). Interviewees were selected either on basis of a mapping exercise of the public organizations involved in Norway and Sweden's management of $A M R$, or after having been identified as key persons by other interviewees. Most interviews were face-to-face, but due to geographical distance and (more lately) the Covid-19 outbreak, some were completed by phone or video conferencing. A potential weakness of the article relates to the breadth of the interview data. Especially the Norwegian case could have benefitted from more interviewee accounts. However, since many of the interviewees are key senior personnel with long-standing contributions to the management of AMR, we consider the overall accounts to cast invaluable light on the article's research questions.

\section{Findings}

\subsection{Sweden's Responses to $A M R$}

\subsubsection{Basic Administrative Structures}

Swedish public administration is, among other things, characterized by dualism and local self-government (Hall, 2016). Dualism implies that most state-level resources and expertise are located at the agency-administrative 
level. The ministries, in turn, are relatively small. All decisions by the Government ministries are settled collectively. This means a "ban on ministerial rule" of the agencies (Bäck \& Larsson, 2008, p. 176; Hall, 2016, p. 3). Swedish state agencies are thus entitled to autonomy, especially in recruitment and internal organization (Hall, 2016, p. 4). Swedish local-self-government constrains the state's access to instruct the public administration at local and county level. Agencies in the health and food and veterinary sectors are active in issuing guidelines and recommendations for voluntary adoption at local- and county-level (Interviews D and F, 2019). In the health sector, competence is shared between the municipalities, county councils (organizing, financing and provision of care), and the state (responsible for the national health policies; Public Health Agency of Sweden [PHAS], 2014, p. 20). The county medical officer manages communicable disease prevention and control within their county, whereas PHAS coordinates communicable disease prevention and control at state-level (Swedish Parliament, 2020, Chapter 1, para. 7-10). In the food and veterinary sector, the state shares competence with the counties and the EU-level. The county council with the county veterinarian manages disease prevention and control on delegated authority from the Swedish Board of Agriculture (SBA; state-level management of risks to animal health) and the Swedish Food Agency (SFI; state-level management of risks to food safety). The National Veterinary Institute manages the monitoring of risk, assessment of and preparedness for animal- and food-borne disease. The Government, including the agencies, respond to the European Commission which enforces the EU's food and veterinary policies.

\subsubsection{AMR Pre-2015}

The first Swedish action plan on AMR (the SPARplan) came in 2000. Written by the National Board of Health and Welfare (NBHW; state-level coordinator of disease prevention and control until 2014) together with relevant authorities, organizations, and the Swedish Strategic Programme Against Antibiotic Resistance (STRAMA; see below), the SPAR-plan emphasised "adequate" monitoring procedures, prudency in antibiotic consumption, and a cross-sectoral approach to AMR (PHAS, 2014, p. 23). In 1999 and 2001, Sweden initiated national programs to monitor AMR and antibiotic consumption in the food and veterinary (SVARM under the National Veterinary Institute) and the health (SWEDRES under PHAS) sectors. These were to provide data to the European surveillance networks on $A M R$ and antibiotic consumption (initiated in the late 1990s). In 2006, the Swedish Parliament endorsed the Government's strategy on AMR and healthcareassociated infections (HAls; PHAS, 2014, p. 23). The strategy was a continuation of the SPAR-plan. It was published by the Ministry of Health, and complemented by Ministries such as Enterprise (agriculture, food and veterinary) and Environment (Government Offices of Sweden, 2005). In 2010, the Government commissioned the NBHW to evaluate and issue recommendations on further steps. The NBHW then invited the EU's agency for disease prevention and control (ECDC) to assess Swedish work on AMR. Emphasising previous Recommendations (European Council, 2001, 2009), the ECDC identified shortcomings in the inter-sectoral structuring of what were otherwise very good sector accomplishments (Government Offices of Sweden, 2012, p. 2; Interview H, 2019). Thus, the Government Offices of Sweden (2012) instructed the NBHW and SBA to set up a coordinating mechanism to facilitate inter-sectoral activities and information exchange on AMR. The mechanism was, however, a formalization of pre-existing patterns of interaction (PHAS, 2014, p. 33). These had been promoted by the profession-driven initiation in 1995 of the STRAMA, to transcend the human and food and veterinary sectors and preserve antibiotics' efficiency (PHAS, 2014 , p. 30). STRAMA came to consist of local, informal, networks (one in all counties) and one state-level network with state agencies and professional associations. By 2010, the state-level STRAMA had been incorporated into the state to facilitate information exchange across sectoral and territorial boundaries (PHAS, 2014, p. 31).

\subsubsection{AMR Post-2015}

Shortly before the Global Action Plan on AMR (GAP; WHO, 2015) was published, the agencies of the mechanism presented a new action plan on $A M R$ and HAls (NBHW, 2015). The six objectives (NBHW, 2015, pp. 17-19) of the action plan contained inter-sectoral (I-II), and sector-specific activities (III-VI) in the health, food and veterinary, and environment sectors. The 20 agencies of the mechanism voluntarily committed to follow-up the action plan. There was no additional funding from the Government; hence, the emphasis on activities to involve a minimum of two agencies, and being in line with agencies' jurisdictions and activity plans.

In 2016, the Government Offices of Sweden (2016) issued a new Swedish strategy on AMR, published by the Ministry of Health, but, referring to One Health, signatories also included the Ministers for Health, Rural Affairs, and Higher Education. The inter-ministerial coordination on AMR had, puzzlingly, given the rule on collective decision-making, been considered insufficient for some time (Interviews $\mathrm{F}$ and $\mathrm{H}, 2019$ ). Responding to agency calls (PHAS, 2016, p. 7), the Government enacted an interministerial working group to facilitate information sharing and follow-up of the strategy. The Government Offices of Sweden's (2016, p. 2) seven strategic objectives provided welcome direction for the mechanism's agencies on what/where to focus efforts at national and international levels (Interviews $\mathrm{G}$ and $\mathrm{H}, 2019$ ). In conjunction with the renewal of the mechanism's mandate (2018-2020), the agencies revised their action plan to accommodate objectives and activities to the strategy (Government Offices of 
Sweden, 2017, p. 1; PHAS, 2017, p. 5). The Government Offices of Sweden (2017) simultaneously decided to designate both the PHAS and SBA as chairs of the mechanism (annual rotation). Compared to the 2012-2017 mandate where PHAS was chair, the food and veterinary, and health sectors with the new mandate were recognized as equals (Interview D, 2019). Finally, to strengthen participation in the follow-up of activities within the mechanism, the Government Offices of Sweden (2017) forwarded the instruction to all 20 agencies. Despite the added constraint on agency autonomy, this move was asked for in two consequent evaluations by the agencies themselves (PHAS, 2016, p. 6; SBA, 2019, p. 7).

The Government Offices of Sweden (2016, p. 17) strategy stipulated that Swedish leadership was to promote the AMR issue within the EU and in international cooperation. Thus, "if overuse of antimicrobials brings harmful effects in Sweden, it has similar effects elsewhere" (Interview D, 2017). In parallel to the 'EU-track,' where Swedish efforts focus on keeping AMR on the European Council and Commission's agenda (Interview $M, 2017)$, Sweden has raised the issue within the Nordic Council of Ministers. However, Nordic cooperation does not seem to constitute the main pillar of Swedish AMR diplomacy (Interviews M, 2017; O, 2019). Collaboration instead is found in alliances such as the Swedishlaunched Alliance of Champions from 2015, with participation from Nordic (Norway), European (Germany, the Netherlands, the UK), African, American, and Asian partner countries (Government Offices of Sweden, 2015, 2020, pp. 15-17).

\subsection{Norway's Responses to $A M R$}

\subsubsection{Basic Administrative Structures}

Norway, much like Sweden, has a public administration characterized by local self-government. The primary healthcare services (such as nursing homes and the General Practitioner [GP] scheme) in Norway are run by the local municipalities with the municipal medical officer managing local-level disease prevention and control (Norwegian Parliament, 2020, para. 7-1, para. 7-2). The specialist care institutions (hospitals, laboratories, etc.) are run by four health enterprises each with a relatively high degree of autonomy within its region. These are owned and governed by the Ministry of Health and Care Services. The main state-level agencies involved in disease prevention and control are the Norwegian Directorate of Health ( $\mathrm{NDH}$; manages the health policies set by the ministry) and the Norwegian Institute of Public Health (NIPH; monitors the national epidemiological situation, provides knowledge for the NDH's managerial functions, has operative responsibility for national infectious disease outbreaks). The overall responsibility for health policies lies with the Ministry of Health. The food and veterinary sector has less local self-government. Thus, the Norwegian Veterinary Institute monitors and assesses the risk from animal- and food-borne disease. The Norwegian Food Safety Authority (NFSA) is the competent authority in Norway for ensuring that plants, fish, animals, and foodstuffs are safe. NFSA is subordinate to the Ministry of Health, Ministry of Agriculture and Food, and Ministry of Trade, Industry, and Fisheries, all of which have specific responsibilities for the food and veterinary sector. Norwegian ministers are subjected to ministerial responsibility. Thus, each minister answers directly to Parliament on the affairs within their designated sector. This implies a clear subordination of food and veterinary agencies to their parent ministry, but also the EU/EEA-legal regime to which corresponding Norwegian regulations must comply.

\subsubsection{AMR Pre-2015}

Prepared in 1999 by an inter-agency working group led by the NIPH, the first Norwegian action plan (2000-2004) on AMR was depicted as being "pioneering work" due to its cross-sectoral perspective (NIPH, 1999, 2005, p. 3). Five ministries were behind the plan whose overiding goal was the preservation of antibiotics' efficacy (NIPH, 1999, p. 12, 2005, p. 6). The objectives covered knowledge needs, antibiotic consumption, infection control, and included the provision of data to European surveillance networks. In 2000, two programs to monitor AMR and antibiotic consumption were established: one for humans (NORM, coordinated by the University Hospital of North Norway) and one for animals (NORM-VET, coordinated by the Norwegian Veterinary Institute). The siting of NORM at a University Hospital ended a dispute between hospital laboratories (longstanding performers of AMR monitoring) and the NIPH over the program's location (Interview Q, 2020). In 2003, the NDH drafted another action plan (2004-2006) on hospital infections. Finalized by the Norwegian Ministry of Health (2004), one out of three objectives covered antibiotic consumption and AMR. After these two action plans expired, the activity level dropped, however (Interview Q, 2020). Thus, under the coordination of NIPH, a national strategy (2008-2012) was drafted (Norwegian Ministry of Health and Care Services [Norwegian Ministry of Health], 2008, pp. 8-9). Finalized by an interministerial steering group with five ministries, the strategy marked a continuation of the intersectoral approach to AMR. Noteworthy, at some stage, it was decided not to copy the Swedish STRAMA model to coordinate the implementation of AMR measures (Interview Q, 2020). The transboundary nature of AMR meant the potential intrusion into several policy sectors with marked jurisdictions. There was also uncertainty as to the county medical office's suitability to both support the municipalities with AMR and perform its function as a supervisory authority (Interview P, 2020). Whereas in Sweden the county medical officer provides a linkage between the local, regional, and statal, many in Norwegian primary care consider the office a "proxy state police authority not to be dealt with" (Interview Q, 
2020). Ultimately, it was decided to work with the existing organizational structures, thus implementing measures sector by sector (Interviews P and Q, 2020).

\subsubsection{AMR Post-2015}

Aided by the momentum at the international level (Interview Q, 2020), agency personnel and experts in 2013 were instructed to prepare a new national strategy on AMR. The interim expert group was yet again intersectoral. New was the emphasis on 'One Health' as reflected in the expert participation from agriculture, fishery, environment, and health (NIPH, 2014, p. 6). The final report identified knowledge gaps in Norway's approach to AMR. Referring to the urgency of the AMR problem plus the limited time to complete the report, the expert group identified cross-sectoral measures amenable to swift implementation (NIPH, 2014, pp. 5-6). The national strategy was finalized in 2015 with the Minister of Health, the Minister of Fisheries, the Minister of Agriculture and Food, and the Minister of Environment as signatories-emphasising its accordance with the GAP (Norwegian Ministry of Health, 2015, p. 7). Different from the previous policy approaches, the national strategy had measurable and verifiable objectives (Norwegian Ministry of Health, 2015, p. 7; Interview Q, 2020). The Norwegian Parliament had decided for the strategy to target a 30 percent reduction by 2020 (compared to the 2012 level) in the population's antibiotic consumption (Interview P, 2020). By 2018, the reduction was reportedly 24 percent (Norwegian Directorate of Health, 2019, p. 4). The strategy had four cross-sectoral objectives, including one on international, normative work, plus sector-specific objectives and eight prioritized areas of action (Norwegian Ministry of Health, 2015, pp. 8-19). An interministerial working group was to follow up on the strategy's implementation. It was decided that action plans should be drafted on the objectives specific to the health and food and veterinary sectors. In the health sector, the NIPH, together with agencies and expert communities, drafted the action plan for the ministry (Norwegian Ministry of Health, 2016, pp. 3, 22). The action plan targeted primary, specialist, dental care, the general population, and the state-level organizing of work (Norwegian Ministry of Health, 2016, p. 4). The ministry decided for an inter-agency steering group - the NDH (lead), NIPH, Norwegian Medicines Agency, and Norwegian Directorate of eHealth-to coordinate the follow-up of the action plan. In 2019, yet another action plan (2019-2023) was added by the Norwegian Ministry of Health $(2019, p, 6)$. Besides a situation report on Norwegian infection control (NIPH, 2018), this action plan built on the ECDC's $(2019$, p. 2) recommendation of a "rapid step-up of infection prevention and control in [Norway, to contain] VRE, CRE, and other emerging multidrug-resistant bacteria." The action plan on the objectives specific to the food and veterinary sector was published by the Norwegian Ministry of
Agriculture and Food (2016) with inputs from the NFSA, Norwegian Veterinary Institute, and industry representatives. Structured around the national strategy's eight areas of action, it was to be dynamic, thus allowing for amendment while respecting the existing budgetary limits (Norwegian Ministry of Agriculture and Food, 2016, pp. 1-2). Different from the approach in health, the ministry coordinated the implementation, and emphasised in its reporting both the national and international objectives of the national strategy.

Like Sweden, Norway's national strategy addressed the need to be a driver of international, normative work on AMR (Norwegian Ministry of Health, 2015, p. 8). Norway stressed the need for Nordic collaboration to promote joint positions at the EU and international level (Norwegian Ministry of Health, 2015, p. 17). In 2017, during its presidency of the Nordic Council of Ministers, the Norwegian Government hosted a Nordic seminar on AMR (to which the EU Commissioner for Health and Food safety gave the opening speech; Norwegian Ministry of Education and Research, 2018, p. 23). After the seminar, the Norwegian Government (2017) conveyed its ambition to take a leading role in the global fight against AMR. Echoing Sweden, Norway's diplomatic work on $A M R$ at the international level seems largely structured around broader alliances, such as Friends of AMR (including Norway, Sweden, Denmark, and a number of other Western countries) and the Alliance of Champions.

\subsection{Adapting Nordic Cooperation to $A M R$}

Nordic cooperation on health has primarily been a "platform for inter-Nordic diffusion and transnational learning" (Kettunen, Lundberg, Østerberg, \& Pedersen, 2016, p. 69), thus, developing what can be labelled a "Nordic epistemic community" (Haas, 2016; Kettunen et al., 2016, p. 69). Although Nordic health systems share some key characteristics such as an emphasis on the active role of the state and universal health coverage, they have also chosen different ways of organizing their health sectors regarding, among other things, the role of private service providers and the allocation of responsibilities between levels of government. The Nordic countries have established a framework for cooperation on health and social affairs based on 'soft' coordination mechanisms. The Nordic Council's Secretariat is responsible for the day-to-day running of intergovernmental cooperation. The Nordic Committee of Senior Officials for Health and Social Affairs consists of representatives from all Nordic countries, meets several times each year, and prepares the meetings of the Nordic Council of Ministers for Health and Social Affairs.

The AMR problem has been discussed among health bureaucrats and professional experts in the Nordics for many years. A Nordic expert group was established in 2013 , followed by a strategy group in 2015 . The strategy group was given the mandate "to use the Nordic collaboration to support the work being coordinated inter- 
nationally in e.g., the EU, WHO, FAO and OIE in order to address antimicrobial resistance" (Nordic Council, 2017, p. 9). However, as of 2017, no proper proposal from this group had been submitted. Thus, the first real attempt to "outline political initiatives and specific proposals for Nordic solutions in the fight against AMR" was not made until 2017 when the Nordic Council published a white paper on Nordic initiatives in the area of AMR (Nordic Council, 2017, p. 9). The white paper was published on the background of the report from 2014 on the future Nordic cooperation on health (Könberg, 2014), and the Nordic Council of Ministers for Health and Social Affairs' Declaration on Antimicrobial Resistance through a One Health Perspective from September 2015. The Declaration stated, among other things, that the Nordic countries agree "to strengthen the Nordic collaboration to maintain a low level of antimicrobial resistance and prudent use of antimicrobials," "support exchange of best practice and ensure an efficient use of the Nordic resources," and "use the Nordic collaboration to support the work being coordinated internationally" (Nordic Council of Ministers for Health and Social Affairs, 2014). The white paper of 2017 outlines twelve initiatives for Nordic cooperation on AMR, including an emphasis on solutions that utilize existing and new instruments, stakeholders that would help find the solutions, as well as the Nordic Region's role in a broad global response to AMR (Nordic Council, 2017, p. 11). Most of the initiatives $(1-7,9)$ are related directly or indirectly to medical practices and innovations. However, some of the initiatives also refer to administrative and institutional issues: 8) Nordic institutions and online database in the area of microbiology; 10) Co-ordination of food control and allocating responsibilities between national bodies in the Nordic Region; 11) A coordinated approach to the impact of relevant EU regulation and legislation, and to the international dissemination of Nordic experiences in combating AMR; 12) A joint Nordic action plan, complete with details of funding, reporting and political control. The white paper further states that "it may prove impossible to cover all of the points," but also that it is "crucial to draw up a Nordic action plan for dealing with any epidemic or similar immediate health disaster" (Nordic Council, 2017, p. 41).

In accordance with the EU's action plans and GAP, the plans for Nordic cooperation are framed within the 'One Health' approach. However, the Nordic Council does not in the white paper specify how this approach can be operationalized in the context of Nordic cooperation. Generally, the Nordic initiatives do not represent any major changes in Nordic cooperation. The initiatives are mostly in line with previous cooperation on health, containing proposals for joint research, funding, information exchange, and flexible coordination, primarily supplementing and building on existing arrangements. Despite the ambition of using Nordic collaboration in international AMR diplomacy, few joint initiatives have emerged since the white paper of 2017. There is a regu- lar exchange of written reports and collaboration on joint statements, but, as yet, no further specification of Nordic measures has been made (Interview N, 2019).

\section{Discussion: Nordic Adaptation to AMR Management}

\subsection{Adaptation: Internal Factors}

The stories of Norway and Sweden's administrative approach to AMR neatly meet the characteristics of an incremental course of development. Besides constituting step-by-step evolving formations of the late 1990s, the two countries' trajectories highlight how distinct institutional settings enable and/or constrain 'better coordination' on AMR. Thus, the upper tier of administration, the ministries, seem more closely involved in AMR policy and management in Norway (ministerial responsibility) than Sweden (collective decision-making). In Norway, public health officials in the Ministry of Health have repeatedly elevated the AMR issue onto the Ministry's agenda (Interview Q, 2020). In Sweden, the Government's lead on the AMR issue seems to rest with the agencies to a greater degree-hence, the pronounced expert rule on the matter. Building on STRAMA and longstanding cooperation on zoonoses, the agencies in the health, food and veterinary sectors have created an intersectoral coordination structure (also including environmental agencies). Norway's approach to AMR seems less streamlined regarding coordination structures; there is an emphasis on the inter-sectoral 'One Health' principle, but the agency structures to follow up the national strategy and action plans (2015-2020) mainly facilitate coordination within policy sectors. Thus, we observe that the organization of AMR management, to a high degree, follows sector competence and responsibilities. Norway's subordination of the state administration to sector ministries is suggestive of a 'sector first' mindset, which reflects a threshold to intersectoral coordination beyond the necessary. This sentiment also is alive and well at the agency-administrative level in Sweden (Time, 2019). However, 'the sector first' mindset is likely to be weaker in Sweden given the collective decision making within the Government Office. Swedish agency officials might thus be more accustomed to coordination that goes beyond their sector, at least within the upper tiers of the administration.

In light of these observations, the article finds limited support for the assumption that AMR constituted a major event-a critical juncture-that brought major changes to administrations in Norway and Sweden and to Nordic cooperation. However, the article provides support to our assumption that adaptation to the AMR challenge is path-dependent as our findings reveal that AMR initiatives have been added to (and do not replace or radically change) the existing governance structures relating to disease prevention and control. This addition has in turn been elevated to become a global, European, and Nordic issue. 


\subsection{Adaptation: External Factors}

Since the beginning of the 2000s, the AMR problem has received increased political attention (Kahn, 2016). International organizations have become important as arenas for information exchange and as sources of proposals on how to manage AMR. The question is whether, and, if so, how the global and European work on AMR has influenced AMR management in the Nordics.

It is important to make a distinction between the management of AMR within the food and veterinary sector, where EU competences are strong, and management of AMR within the health sector, where EU competences are weak (Hervey \& McHale, 2015). Both Sweden and Norway are part of the Europe-wide system for food and animal inspection and control and are thus required to implement and adhere to EU/EEA legislation in this area (Ugland \& Veggeland, 2006). However, even in these sectors, there is wide variation within Europe regarding the use of antibiotics for animals, the prevalence of AMR in livestock, and how to manage the problems (Interview J, 2017). Thus, although the EU has 'penetrated' national systems of governance on selected areas, national administrations have preserved their distinct national characteristics.

According to Art. 168 of the Treaty on the Functioning of the European Union, the "responsibilities of the Member States shall include the management of health services and medical care and the allocation of the resources assigned to them" (Consolidated version of the Treaty on the functioning of the European Union, 2012, article 168). Thus, the EU relies mostly on non-binding methods of coordination in the health sector. This takes place through a number of meetings and networks involving politicians, senior officials, and experts. Two examples are the Health Security Committee (includes the health sector) and the EU AMR One-Health Network (includes both the health and veterinary sectors) where Commission officials and national representatives meet (Norway as an observer). The Health Security committee is designated to support information exchange and to coordinate the management of and responses to health crises, including AMR. The task of the AMR One-Health Network is to "present national action plans and activities, share best practices, discuss policy options and enhance coordination" (European Commission, 2019). In the context of European cooperation, however, Norway and Sweden seem to perceive themselves more as role models than as passive receivers of EU influence when it comes to AMR management. Sweden, for example, had an active role (supported by the other Nordic countries) in the process leading up to the $2006 \mathrm{EU}$ ban on the use of antibiotics as growth promoters in food animals (Edqvist \& Pedersen, 2001; European Council, 1998; European Commission, 1998; Interview D, 2017). All Nordic countries have emphasized international dissemination of Nordic experiences in combating AMR and all have agreed on the ambition of using Nordic collab- oration to promote Nordic AMR strategies internationally (Nordic Council, 2017). Thus, although Norway and Sweden so far appear as the most active among the Nordic countries, 'Nordification' of AMR strategies in Europe may, in fact, better characterize the development than 'Europeanization' of Nordic strategies.

The WHO created momentum for its role in AMR management when it published the GAP in 2015. Two elements stand out in this plan: the urge for member states to have in place national action plans within two years, and the emphasis on a 'One Health' approach. Norway and Sweden have developed national action plans in accordance with the WHO recommendation and both countries emphasize the 'One Health' approach. However, on closer examination of the details of strategies/action plans and the (lack of) operationalization of the 'One Health' approach, it becomes clear that the influence of global ideas on national management strategies and administrative structures is limited.

The Nordic initiatives for strengthening cooperation on AMR include both the emphasis on 'One Health' and the aim of developing a Nordic action plan. However, so far, these initiatives have not really contributed to any substantial change in the framework for Nordic cooperation; AMR management remains a national prerogative and Nordic cooperation in the health area remains limited. The limited convergence of administrative structures and the limited progress in further developing the Nordic cooperation can be explained by governments' protection of national sovereignty in the health area, as well as by path-dependent ways of organizing and managing emerging health challenges. In the Nordic response to $A M R$, there is much emphasis on the advantages of the 'Nordic model' and the success of Nordic countries in fighting AMR. Nordic adaptation to AMR is, however, more characterized by ambitions of exporting ideas and solutions to international organizations than on the need for the Nordics to implement ideas and recommendations from the international level. A comment made by a Norwegian public official illustrates this point: "If the whole world had been like Norway and Sweden, then the consumption of antibiotics and management of disease prevention would have been a phenomenon, not a problem" (Interview Q, 2020). Generally, external factors seem to have limited importance for Nordic systems for AMR management. Thus, the article's findings do not support the assumption that EU influence surpasses Nordic approaches and lead to European specific solutions to the management of the AMR crisis. Neither do the findings support the assumption that global initiatives and diffusion of norms, standards, and ideas, have contributed to the convergence of national systems of AMR management. Even though the Nordic countries, as well as the $E U$, lend support to the idea of adapting AMR management to the 'One Health' principle, so far this idea seems to be characterized more by 'branding' than as an operational guiding principle for converging developments in the administrative structures for AMR management. 


\section{Summarizing Conclusions}

The central administrative systems of Norway and Sweden have adapted to AMR by supplementing sector responsibility with coordinating mechanisms within the upper tiers of government while leaving the operative responsibility to sector authorities. For Norway, AMR management is mainly taking place within existing administrative structures with only weak coordination mechanisms. Sweden has over time established a more comprehensive coordination system for ministries and agencies (cf. 'the coordinating mechanism'/STRAMA). However, even in Sweden, the operative AMR work takes place according to sectoral lines in government and according to the basic established administrative system for disease prevention and control. The Nordic countries have responded to AMR by emphasising the need for strengthening Nordic cooperation. However, the Nordic Council responded late, coming up with new initiatives as late as 2017, and the initiatives moreover do not really represent major steps forward in strengthening cooperation. Instead, the Nordic initiatives signal an incremental approach where ambitions are relatively low. AMR management supplements existing systems without substantially changing neither the national administrations nor the Nordic cooperation framework, thus highlighting the importance of both pathdependency in governmental structures and the traditional emphasis on national sovereignty in the health sector. The Nordic countries' ambition of being frontrunners in AMR management has added to the limited international influence on their administrative systems. Turning back to our assumptions about Nordic adaptation: There are few signs of EU influence contributing to standardized/Europeanized solutions to AMR management in the Nordic administrations, except for a few areas where EU competences and/or common interests are strong. Thus, we do observe some convergence in the food and veterinary area, although such convergence primarily appears in strategies and legal measures and less in administrative adaptations. Global initiatives have contributed to the diffusion of ideas on AMR. However, the 'convergence' between administrative systems caused by such ideas appears mostly as 'window-dressing,' i.e., by the inclusion of 'fashionable' concepts such as 'One Health' without making substantial changes to the systems. Thus, AMR management in the Nordics is characterized by incremental change within existing structures of disease prevention and control and on traditional ways of organizing political and administrative systems. The findings of the article thus reveal some of the conditions for (and limitations of) institutional change and highlight the importance of considering the variation of historical developments and institutional contexts when understanding the adaptations of administrative systems to the AMR challenge. The article thus adds to the literature on how and why (multiple) administrative systems respond to major external challenges.

\section{Acknowledgments}

The authors would like to thank the editors for inviting us to contribute to this thematic issue. We are grateful to the interviewees who provided invaluable information to our study, and to the editors and three referees for their comments on our article. The work of the article is partly associated with the research project STOPPest (Risk management of imported plants and seeds: Possibilities for improved pest detection to prevent the introduction and spread of new pests), managed by NIBIO and financed by the Norwegian Research Council.

\section{Conflict of Interests}

The authors declare no conflict of interests.

\section{Supplementary Material}

Supplementary material for this article is available online in the format provided by the author (unedited).

\section{References}

Bäck, H., \& Larsson, T. (2008). Governing and governance in Sweden. Lund: Studentlitteratur.

Bondarouk, E., \& Mastenbroek, E. (2018). Reconsidering EU compliance: Implementation performance in the field of environmental policy. Environmental Policy and Governance, 28(1), 15-27.

Boxenbaum, E., \& Jonsson, S. (2017). Isomorphism, diffusion and decoupling: Concept evolution and theoretical challenges. In R. Greenwood, C. Oliver, T. B. Lawrence, \& R. E. Meyer (Eds.), The SAGE handbook of organizational institutionalism (2nd ed., pp. 79-104). Thousand Oaks, CA: SAGE.

Cassini, A., Högberg, L. D., Plachouras, D., Quattrocchi, A., Hoxha, A., Simonsen, G. S., . . Monnet, D. L. (2018). Attributable deaths and disability-adjusted life-years caused by infections with antibiotic-resistant bacteria in the EU and the European Economic Area in 2015: A population-level modelling analysis. The Lancet Infectious Diseases, 19(1), 56-66.

Consolidated version of the Treaty on the Functioning of the European Union, 2012/C 326/01 (2012).

DANMAP. (2019). Use of antimicrobial agents and occurrence of antimicrobial resistance in bacteria from food animals, food and humans in Denmark, 2018. Copenhagen and Lyngby: Statens Serum Institut and National Food Institute.

ECDC. (2018). Surveillance of antimicrobial resistance in Europe: Annual report of the European Antimicrobial Resistance Surveillance Network (EARS-Net). Stockholm: European Centre for Disease Prevention and Control.

ECDC. (2019). ECDC country visit to Norway to discuss antimicrobial issues 12-16 March 2018. Stockholm: European Centre for Disease Prevention and Control. 
ECDC. (2020). Rates by country. Antimicrobial consumption database (ESAC-Net). Retrieved from https:// ecdc.europa.eu/en/antimicrobial-consumption/ database/rates-country

Edqvist, L. E., \& Pedersen, K. B. (2001). Antimicrobials as growth promoters: Resistance to common sense. In P. Harremoës, D. Gee, M. MacGarvin, A. Stirling, J. Keys, B. Wynne, \& S. G. Vaz (Eds.), Late lessons from early warnings: The precautionary principle 1896-2000 (pp. 93-100). Copenhagen: European Environment Agency.

European Commission. (1998). Commission regulation (EC) of 22 December 1998 amending Council Directive 70/524/EEC concerning additives in feedingstuffs as regards the withdrawal of authorisation for certain growth promoters (No. 2788/98). Brussels: European Commission.

European Commission. (2017). A European One Health action plan against Antimicrobial Resistance (AMR). Brussels: European Commission.

European Commission. (2019). AMR One Health Network (15 October 2019). European Commission. Retrieved from https://ec.europa.eu/health/amr/ events/ev_201910151_en

European Council. (1998). Council regulation (EC) of 17 December 1998 amending, as regards withdrawal of the authorisation of certain antibiotics, directive $70 / 524 /$ EEC concerning additives in feedingstuffs (No. 2821/98). Brussels: European Commission.

European Council. (2001). Council recommendation of 15 November 2001 on the prudent use of antimicrobial agents in human medicine (2002/77/EC). Brussels: European Commission.

European Council. (2009). Council recommendation of 9 June 2009 on patient safety, including the prevention and control of healthcare associated infections (2009/C 151/01). Brussels: European Commission.

European Council. (2016, June 17). Council conclusions on the next steps under a One Health approach to combat antimicrobial resistance [Press release]. Retrieved from https://consilium.europa. eu/en/press/press-releases/2016/06/17/epscoconclusions-antimicrobial-resistance

European Medicines Agency. (2019). Sales of veterinary antimicrobial agents in 31 European countries in 2017. Amsterdam: European Medicines Agency. Retrieved from https://ema.europa.eu/en/ documents/report/sales-veterinary-antimicrobialagents-31-european-countries-2017_en.pdf

Government Offices of Sweden. (2005). Strategi för ett samordnat arbete mot antibiotikaresistens och vårdrelaterade sjukdomar [Strategy for a coordinated work against antibiotic resistance and healthcare associated diseases] (Government proposition No. 2005/06:50). Stockholm: Government Offices of Sweden.

Government Offices of Sweden. (2012). Uppdrag inom strategin mot antibiotikaresistens och vårdrelater- ade infektioner [Government mission concerning the strategy against antibiotic resistance and healthcare associated infections] (S2010/7655/FS). Stockholm: Ministry of Health and Social Affairs.

Government Offices of Sweden. (2015, June 11). The Alliance of Champions: The fight against antimicrobial resistance (AMR) [Press release]. Retrieved from http://swemfa.se/2015/06/11/the-allianceof-champions-the-fight-against-antimicrobialresistance-amr

Government Offices of Sweden. (2016). Swedish strategy to combat antibiotic resistance. Stockholm: Ministry of Health and Social Affairs.

Government Offices of Sweden. (2017). Uppdrag angående samverkansfunktion och handlingsplan för arbetet mot antibiotikaresistens [Government mission concerning the coordinating mechanism and the action plan for the work against antibiotic resistance] (S2017/01706/FS). Stockholm: Ministry of Health and Social Affairs.

Government Offices of Sweden. (2020). Svensk strategi för arbetet mot antibiotikaresistens 2020-2023 [Swedish strategy for the work against antibiotic resistance 2020-2023]. Stockholm: Ministry of Health and Social Affairs.

Haas, P. M. (2016). Epistemic communities, constructivism, and international environmental politics. London and New York, NY: Routledge.

Hall, P. (2016). The Swedish administrative model. In J. Pierre (Ed.), The Oxford handbook of Swedish politics. Oxford: Oxford University Press. https://doi.org/ 10.1093/oxfordhb/9780199665679.013.17

Hervey, T. K., \& McHale, J. (2015). European Union health law: Themes and implications. Cambridge: Cambridge University Press.

Kahn, L. H. (2016). One Health and the politics of antimicrobial resistance. Baltimore, MD: John Hopkins University Press.

Kettunen, P., Lundberg, U., Østerberg, M., \& Pedersen, K. (2016). The Nordic model and the rise and fall of Nordic cooperation. In J. Strang (Ed.), Nordic cooperation: A European region in transition (pp. 69-92). London and New York, NY: Routledge.

Kingdon, J. W. (1995). Agendas, alternatives and public policies. New York, NY: HarperCollins College Publishers.

Könberg, B. (2014). The future Nordic co-operation on health. Copenhagen: Nordic Council of Ministers.

Lindblom, C. E. (1959). The science of "muddling through." Public Administration Review, 19(2), 79-88.

Mahoney, J., \& Thelen, K. (2010). A gradual theory of institutional change. In J. Mahoney \& K. Thelen (Eds.), Explaining institutional change: Ambiguity, agency, and power. Cambridge: Cambridge University Press.

NBHW. (2015). Handlingsplan mot antibiotikaresistens och vårdrelaterade infektioner [Action plan against antibiotic resistance and healthcare associated infec- 
tions]. Stockholm: National Board of Health and Welfare.

NIPH. (1999). Plan for å motvirke antibiotikaresistens [Plan to counteract antibiotic resistance]. Oslo: Norwegian Institute of Public Health. Retrieved from https://regjeringen.no/no/dokumenter/plan-for-amotvirke-antibiotikaresistens/id101959

NIPH. (2005). Evaluering og videreføring av Regjeringens tiltaksplan mot antibiotikaresistens 2000-2004: Rapport fra Folkehelseinstituttets konferanse 14.-15. september 2004 [Evaluation and continuation of the Government's Action Plan against antibiotic resistance 2000-2004: Report from the Norwegian Institute of Public Health conference 14-15 September 2004]. Oslo: Norwegian Institute of Public Health.

NIPH. (2014). Antibiotikaresistens-kunnskapshull, utfordringer og aktuelle tiltak. Rapport fra tverrsektoriell ekspertgruppe [Antibiotic resistance-Gaps of knowledge, challenges and current measures]. Oslo: Norwegian Institute of Public Health.

NIPH. (2018). Situasjonsbeskrivelse av smittevern $i$ Norge: med fokus på forebygging av Helsetjenesteassosierte infeksjoner og tiltak for å unngå at resistente mikrober etablerer seg i norsk helsetjeneste [Situational description of infection control in Norway: With a focus on the prevention of healthcare associated infections and measures to avoid the establishing of resistant microbes in the Norwegian health sector]. Oslo: Norwegian Institute of Public Health.

Nordic Council. (2017). 12 initiatives: Nordic cooperation on combating antimicrobial resistance-A white paper outlining new Nordic initiatives. Copenhagen: Nordic Council.

Nordic Council of Ministers for Health and Social Affairs. (2014). Declaration by the ministers of health and social affairs on the future of co-operation on health in the Nordic Region. Copenhagen: Nordic Council of Ministers for Health and Social Affairs. Retrieved from https://www.norden.org/en/declaration/ declaration-ministers-health-and-social-affairsfuture-co-operation-health-nordic

Norwegian Directorate of Health. (2019). 2018: Statusrapport fra styringsgruppen Handlingsplan mot antibiotikaresistens $i$ helsetjenesten 2016-2020 [2018: Status report from the steering committee for the Action Plan against antibiotic resistance in the health sector 2016-2020]. Retrieved from https:// helsedirektoratet.no/rapporter/Statusrapporter\%20 \%20Handlingsplan\%20mot\%20antibiotikaresistens \%20i\%20helsetjenesten\%202016\%E2\%80\%932020

Norwegian Government. (2017, June 27). Norway takes the lead on antibiotic resistance [Press release]. Retrieved from https://regjeringen.no/en/aktuelt/ norway-takes-the-lead-on-antibiotic-resistance/ id2561185

Norwegian Ministry of Agriculture and Food. (2016). Handlingsplan mot antibiotikaresistens innenfor Landbruks-og matdepartementets sektoransvar
[Action plan against antibiotic resistance within the sector responsibility of the Ministry of Agriculture and Food]. Oslo: Norwegian Ministry of Education and Research.

Norwegian Ministry of Education and Research. (2018). Meld. St. 11 (2017-2018): Nordisk samarbeid [Report to the Storting No. 11 (2017-2018): Nordic cooperation]. Oslo: Norwegian Ministry of Education and Research.

Norwegian Ministry of Health. (2004). Handlingsplan for å forebygge sykehusinfeksjoner 2004-2006 [Action plan to prevent healthcare associated infections 2004-2006]. Oslo: Norwegian Ministry of Health and Care Services.

Norwegian Ministry of Health. (2008). Nasjonal strategi for forebygging av infeksjoner $i$ helsetjenesten og antibiotikaresistens (2008-2012) [National strategy for the prevention of infections in the health sector and antibiotic resistance (2008-2012)]. Oslo: Norwegian Ministry of Health and Care Services.

Norwegian Ministry of Health. (2015). National strategy against antibiotic resistance 2015-2020. Oslo: Norwegian Ministry of Health and Care Services.

Norwegian Ministry of Health. (2016). Handlingsplan mot antibiotikaresistens $i$ helsetjenesten: med det mål å redusere antibiotikabruken i befolkningen med 30 prosent innen utløpet av 2020 [Action plan against antibiotic resistance in the health sector: With the aim to reduce the population's antibiotics consumption by 30 percent by the end of 2020]. Oslo: Norwegian Ministry of Health and Care Services.

Norwegian Ministry of Health. (2019). Handlingsplan for et bedre smittevern med det mål å redusere helsetjenesteassosierte infeksjoner 2019-2023 [Action plan for an improved infection control with the aim to reduce healthcare associated infections 2019-2023]. Oslo: Norwegian Ministry of Health and Care Services.

Norwegian Parliament. (2020). Lov om vern mot smittsomme sykdommer [smittevernloven] [The Norwegian Communicable Diseases Act] (LOV-1994-08-0555, Current ver. LOV-2020-04-24-34). Oslo: Norwegian Parliament.

OECD. (2018). Stemming the superbug tide: Just a few dollars more [Policy brief]. Paris: OECD.

Olsen, J. P. (2002). The many faces of Europeanization. Journal of Common Market Studies, 40(5), 921-952.

O’Neill, J. (Ed.). (2014). Review on antimicrobial resistance: Antimicrobial resistance-Tackling a crisis for the health and wealth of nations. London: HM Government and Wellcome Trust. Retrieved from https://amr-review.org/sites/default/files/AMR\%20 Review\%20Paper\%20-\%20Tackling\%20a\%20crisis \%20for\%20the\%20health\%20and\%20wealth\%20of \%20nations_1.pdf

Pedersen, P. J., Røed, M., \& Wadensjö, E. (2008). The common Nordic labour market at 50. Copenhagen: Nordic Council of Ministers. 
PHAS. (2014). Swedish work on containment of antibiotic resistance: Tools, methods and experiences. Solna and Östersund: Public Health Agency of Sweden.

PHAS. (2016). Återrapportering av samordningsuppdrag antibiotikaresistens och vårdrelaterade infektioner, årsrapport 2016 samt utvärdering av samverkansfunktionen [Report to government on the coordinating mission against antibiotic resistance and healthcare associated infections, annual report for 2016 plus evaluation of the coordinating mechanism]. Solna and Östersund: Public Health Agency of Sweden.

PHAS. (2017). Reviderad tvärsektoriell handlingsplan mot antibiotikaresistens 2018-2020: underlag för samverkansgruppens fortsatta arbete [Revision of the cross-sectoral action plan against antibiotic resistance 2018-2020: Basis for the continued work of the coordinating mechanism]. Solna and Östersund: Public Health Agency of Sweden.

Pierson, P. (2000). Increasing returns, path dependence, and the study of politics. The American Political Science Review, 94(2), 251-267.

Pierson, P. (2004). Politics in time: History, institutions, and social analysis. Princeton, NJ, and Oxford: Princeton University Press.
Pollitt, C. (2008). Time, policy, management: Governing with the past. Oxford: Oxford University Press.

SBA. (2019). Aterrapportering av samordningsuppdrag antibiotikaresistens samt årsrapport 2019 [Report to government on the mission of the national coordinating mechanism plus annual report for 2019]. Jönköping: Swedish Board of Agriculture.

Swedish Parliament. (2020). Smittskyddslag [The Swedish Communicable Diseases Act] (2004:168, Current ver. SFS 2020:242). Stockholm: Swedish Parliament.

Time, M. S. (2019). Temporal properties in interorganizational coordination: Sweden's fight against antimicrobial resistance. Paper presented at the 13th ECPR General Conference, Wroclaw, Poland.

Treib, O. (2014). Implementing and complying with EU governance outputs. Living Reviews in European Governance, 9(1). https://doi.org/10.12942//reg-2014-1

Ugland, T., \& Veggeland, F. (2006). Experiments in food safety policy integration in the European Union. Journal of Common Market Studies, 44(3), 607-624.

WHO. (2015). Global action plan on antimicrobial resistance. Geneva: WHO.

\section{About the Authors}

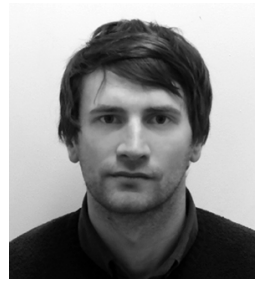

Martin Stangborli Time holds a Master's degree in political science from the University of Oslo. Since 2015, he is PhD Research Fellow in Public Administration at the University of Agder. In 2018-2019 he was Laufer Doctoral Visiting Fellow at the Geschwister Scholl Institute of Political Science, LudwigMaximilians-Universität München. Martin studies the impact of power and temporality on public sector coordination to counteract transboundary challenges. His PhD project focuses on the global fight against antimicrobial resistance.

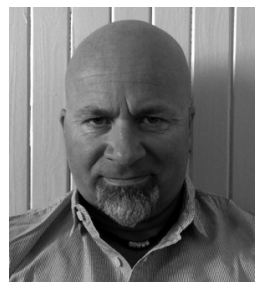

Frode Veggeland holds a PhD in Political Science since 2004. He is Full Professor in public policy at the Department of Health Management and Health Economics, University of Oslo, and Associated Senior Researcher at the Norwegian Institute of Bioeconomy Research. Veggeland's fields of research include food and health policies, international organizations, and EU regulation and governance. He acted as Head of the Secretariat for the Governmental Commission, which investigated the management of the outbreak of E.coli 0103 in Norway, 2006. 